\title{
Escravidão, abolição e gênero: mulheres negras, corpo e reprodução nas Américas
}

\author{
Caroline Passarini Sousa ${ }^{1}$
}

Resumo: Este artigo tem como objetivo refletir sobre a importância do gênero, sobretudo das mulheres negras escravizadas, tanto para a conformação do sistema escravista nas Américas quanto para a sua abolição. Tendo em vista que a escravidão foi cimentada por meio da hereditariedade materna, implementada a partir do princípio partus sequitur ventrem, o objetivo é discutir como estes aspectos impactaram o cotidiano vivido por mulheres escravizadas. Além disso, as experiências de abolição gradual nas Américas, no fim do século XVIII e início do XIX, buscaram romper com partus sequitur ventrem e, novamente, o ventre de mulheres negras foi essencial. Por isso, acreditamos que discutir os mecanismos de escravização em termos de gênero, reconhecendo a importância do corpo, reprodução e maternidade nesse processo, possibilita um alargamento das perspectivas de análise tanto do universo escravista quanto dos processos de abolição da escravidão.

Palavras-chave: escravidão; abolição; gênero

\section{Slavery, abolition and gender: black women, body and reproduction in the Americas}

\begin{abstract}
This article aims to reflect on the importance of gender, especially of black enslaved women, in shaping the slave system in the Americas. Bearing in mind that slavery was grounded on maternal inheritance, implemented through the partus sequitur ventrem principle, the objective is to discuss how these aspects impacted the daily lives of enslaved women. Furthermore, the experiences of gradual abolition in the Americas in the late 18th and early 19th centuries sought to break with partus sequitur ventrem and, again, the womb of black women was essential. Therefore, we believe that discussing the mechanisms of enslavement in terms of gender, recognizing the importance of body, reproduction, and motherhood in this process, enables a broadening of analysis perspectives, both in the slave universe and in the process of slavery abolition.
\end{abstract}

Keywords: slavery; abolition; gender

Artigo recebido em: 31/08/2021

Artigo aprovado para publicação em: 16/11/2021

\footnotetext{
1 Doutoranda e Mestra pelo Programa de Pós-Graduação em História Social (PPGHS-FFLCH/USP). ORCID: https://orcid.org/0000-0002-8843-1918. E-mail carolinepassarini.s@usp.br
} 
O transporte forçado e a escravização de milhões de homens e mulheres africanas para o continente americano (o 'Novo Mundo') possibilitaram a exploração extenuante da mão de obra destes indivíduos, marcando profundamente a formação das sociedades americanas, bem como a história de nações europeias e africanas que participaram ativamente deste sistema. Contudo, juntamente à comercialização desenfreada de pessoas negras africanas pelo atlântico, o processo de consolidação da escravidão, obedeceu, de maneira geral, à hereditariedade da condição escrava. Desde muito cedo coube ao sujeito colonizador, majoritariamente masculino e branco (políticos, legisladores, proprietários), determinar de que maneira a escravidão seria mantida e perpetuada nos novos territórios. A escolha se fez pelo ventre escravo, resgatada de uma tradição legal romana, a condição de escravidão na América foi determinada pelo status das mães: partus sequitur ventrem - o parto segue o ventre. A (suposta) naturalidade da herança escrava foi cuidadosamente manejada para conservar o poder das classes abastadas, atendendo aos interesses de sociedades escravistas e patriarcais. Neste artigo, analisaremos, a partir de uma reflexão historiográfica, a importância do gênero e da raça em dois momentos: a conformação do sistema escravista e a abolição da escravidão nas Américas. ${ }^{2}$

Durante o século XV, a comunicação entre praticamente todas as partes do mundo foi inaugurada pela abertura do trânsito entre os oceanos Atlântico, Índico e Pacífico, a expansão da atividade econômica pelos caminhos então abertos configurou uma nova forma de interação entre 'velho' e 'novo' mundo. Dentro desse contexto e ao longo de três séculos, o estabelecimento da escravidão africana nas Américas foi, supostamente, justificado por diferentes meios como guerras, religião, leis, pela natureza e clima e, por fim, pela 'ciência'.

\footnotetext{
${ }^{2} \mathrm{O}$ termo "Américas" será aqui empregado para se referir ao continente americano como um todo, mas buscando tratar especificamente das relações tecidas com a escravidão. Sendo assim, "Américas" pode abranger reflexões, análises e experiências sobre as antigas colônias inglesas e francesas no Caribe, América do Norte (Estados Unidos), América Latina, Brasil e Cuba.
} 
A religião exerceu um papel fundamental no processo de expansão marítima, tendo Portugal e Espanha como os primeiros protagonistas. Um dos discursos mais difundidos ao longo do século XV e utilizado para justificar a escravidão africana foi o de que ela teria surgido de uma maldição divina, sendo uma consequência direta do pecado de Adão e Eva e, portanto, um símbolo da desgraça humana (OLIVEIRA, 2018, p.29-30). A chamada Maldição de Cam foi outro acontecimento bíblico também utilizado como justificativa para a escravização de pessoas negras. No episódio bíblico, Cam, filho de Noé, ao ver o pai bêbado e nu, chamou seus outros irmãos para ver a cena. O pai, em resposta, teria amaldiçoado a prole do próprio filho com a escravidão.

Santo Agostinho foi o primeiro a apontar uma possível relação entre escravidão e a maldição de Cam, pois neste episódio a palavra 'escravo' foi usada pela primeira vez na narrativa bíblica. Nesse sentido, há um esforço para fundir a imagem do sujeito a ser escravizado com a figura do negro/africano dentro do pensamento cristão, sendo que a cor da pele foi interpretada como um 'sinal' da maldição. A escravidão como resultado de um pecado proporcionou uma oportunidade para que europeus evangelizassem africanos, sob a alegação de afastá-los de seus erros, justificando assim seu cativeiro. Segundo Cleiton Oliveira:

\begin{abstract}
Vários autores do século XV, inspirados ainda pelas marcas de continuidade do imaginário medieval, defendiam que o próprio aspecto físico de Cam, que aparece em várias representações iconográficas como negro, era um sinal externo da maldição divina. Seus descendentes carregariam também a negritude como sinal desse castigo, sendo que parte dessa condenação seria a de viver em uma região de excessivo calor, que contribuía ainda mais para "esturricar" a sua pele, deixando-a com a cor que lembrava trevas. Circulava nos meios eclesiásticos a notícia de um sermão de Santo Ambrósio, que teria afirmado que o nome Cam queria dizer Calidus, isto é, calor (OLIVEIRA, 2018, p.33). [grifo nosso]
\end{abstract}

No âmbito legislativo, "Las Siete Partidas", documento espanhol compilado pelo rei D. Afonso e organizado entre os anos de 1263 e 1265, foi o primeiro documento a garantir já naquela época um 'corpo de leis' para a escravidão forjado no cristianismo. Pautava-se no princípio de que a escravidão contrariava o direito natural - de liberdade, reconhecendo a humanidade de homens e mulheres escravizadas. Em função disso, o código procurava 'garantir' aos escravos condições mínimas de existência e acesso à liberdade por meios das manumissões. 
Para David B. Davis, alguns estudiosos deram muita importância ao fato de que as Siete Partidas reconheciam a liberdade como uma condição natural do ser humano e garantiam alguns 'direitos' aos escravos, como a possibilidade de alforria. ${ }^{3}$ Isso porque, apesar de estipular alguma condição de existência aos cativos, o documento também determinava sua completa subordinação à vontade dos senhores, os quais podiam puni-los severamente e até matá-los em alguns casos.

As Siete Partidas determinavam também três formas pelas quais um indivíduo podia ser considerado escravizado: ser um não cristão capturado em guerra, deixar-se vender voluntariamente, ou nascendo de uma escrava - partus sequitur ventrem (Quarta Partida. Título XXI, Lei 1). ${ }^{4}$ De maneira contraditória, o documento reconhecia a escravidão como algo avesso ao direito natural do ser humano, porém, reconhecia a escravidão por nascimento. $\mathrm{O}$ fator determinante para definir a descendência escrava seria a figura materna, fosse ela livre ou escravizada. Embora no contexto de sua criação o objetivo não fosse instituir normas específicas para as colônias americanas, a escravidão de africanos e africanas, ou o tráfico transatlântico, as Partidas forneceram bases importantes para a regulação do sistema escravista na América espanhola, influenciando diretamente a conformação de um sistema normativo português, também usado posteriormente nas colônias ibéricas (SILVA JÚNIOR, 2018, p.59-61).

No início da chamada 'era das navegações' e dos primeiros contatos entre europeus, africanos e indígenas na América, a autorização para exploração das novas terras, sobretudo para as monarquias católicas, era concedida pela Igreja. Portugal requisitou em 1452 uma bula papal aprovando o seu direito de exploração sobre as novas áreas, suas incursões foram enquadradas como uma espécie de extensão da Guerra Santa instaurada anteriormente contra o Islamismo. Em resposta, a Igreja autorizou portugueses a invadirem, procurarem, capturarem e subjugarem quaisquer 'infiéis' ou 'inimigos de Cristo', reduzindo-os à escravidão. Dois anos depois, essas

\footnotetext{
${ }^{3}$ Alguns estudiosos acabaram interpretando a tradição das Partidas como uma evidência de que a escravidão desenvolvida nos territórios ibéricos - sobretudo no Brasil - seria uma escravidão mais 'branda', menos violenta, se comparada à escravidão observada na porção anglo-saxão da América, por exemplo. Um dos grandes representantes desta linha interpretativa foi Frank Tannenbaum, com sua obra Slave and Citizen, publicada em 1946.

${ }^{4}$ A expressão em latim foi por nós adicionada e não consta no documento em questão.

${ }^{5}$ As bulas papais constituíam-se como elementos legitimadores das conquistas, além de autorizarem oficialmente a escravização das populações negras africanas, atribuindo-lhe papel de grande importância para o serviço de evangelização dessas pessoas. Ver: OLIVEIRA, 2018.
} 
sanções foram reafirmadas e estendidas para qualquer território que pudesse ser conquistado, reconhecendo que os africanos estavam sendo escravizados à força, mas legalmente, em nome da conversão à fé católica. Em 1493, a mesma autorização foi concedida à Espanha pelo Papa Alexandre VI e no ano seguinte o Tratado de Tordesilhas confirmou todas as bulas papais anteriores (DRESCHER, 2011, p.86).

A primeira 'patente' colonizadora inglesa foi concedida pela rainha Elizabeth em 1584 e enquanto no território britânico a escravidão era uma instituição ausente e repudiada, nas colônias recém conquistadas esse regime de trabalho se consagrou em um processo passivo de acomodação legal. Nenhum regulamento publicado na metrópole inglesa jamais cobrou taxa sobre entrada e saída de cativos na metrópole, como era feito nos portos coloniais, por exemplo. Em nenhum lugar, no entanto, fosse em estatutos coloniais, atos parlamentares ou decisões da Coroa, foi desenvolvido algo remotamente similar a uma jurisprudência específica para escravidão - como existiu nas colônias francesas. Não houve discussão no âmbito do direito comum ou civil e nenhum código escravo imperial foi desenvolvido para preencher as diversas lacunas que existiam (DRESCHER, 2011, p.109).

O tráfico atlântico e a posse de escravos foram formalmente sancionados pela França quando Luís XIII fez acordos para converter africanos ao cristianismo em 1648. O Código Negro francês (Code Noir) ${ }^{6}$ foi elaborado pelo Conselho Real da França para ser aplicado exclusivamente nas colônias, enquanto em solo metropolitano o princípio de liberdade permaneceu intacto. Essa foi uma prática comum entre as nações europeias com colônias na América. À medida em que introduziam práticas escravistas nos territórios coloniais, os países europeus buscavam reafirmar seus territórios como lugares exclusivos de liberdade, o chamado princípio de 'solo livre' causaria dificuldades para proprietários que transitassem entre os territórios metropolitanos e as colônias acompanhados de escravizados (DAVIS, 2001, p.64; DRESCHER, 2011, p.91).

Para Seymour Drescher, no início da era moderna, o aspecto que mais distinguiu os ibéricos de outros países europeus (ingleses, franceses, holandeses), onde a escravidão havia

\footnotetext{
${ }^{6}$ Conjunto de ordenações que passaram a regulamentar a vida das pessoas negras, escravizadas ou libertas 
perdido força na Idade Média, foi a presença da escravidão em seus próprios territórios. ${ }^{7}$ Nesse sentido, a existência de algum aparato legal a respeito da escravidão acabou refletindo diretamente sobre as colônias que cada país europeu estabeleceu no Novo Mundo (DRESCHER, 2011, p.16). Em outros países da Europa, o problema em torno da prática e autorização para escravização além dos limites metropolitanos foi resolvido num sentido oposto ao dos países ibéricos, em função da noção de 'solo livre'.

Essas diferenças entre metrópoles e colônias, sobre o princípio de liberdade para pessoas negras ou de ascendência africana, foram questões políticas muito complexas a serem pensadas pelos governos metropolitanos e acabaram moldando oportunidades para diferentes projetos de vida de pessoas recém-saídas da escravidão nos territórios americanos. Essa problemática foi cuidadosamente trabalhada por Rebecca J. Scott e Jean M. Hébrard, em “Provas de Liberdade”, obra em que os autores seguem os deslocamentos de diferentes gerações de uma mesma família negra por terras haitianas, francesas, norte-americanas, cubanas e belgas. A fragilidade desses processos relacionados à liberdade, os perigos de reescravização e o preconceito racial a que 'pessoas de cor' ${ }^{\prime 8}$ estavam sujeitas ao longo dos anos ficam evidentes no livro.

No contexto de seus trânsitos, a família Tinchant, rastreada minuciosamente em diversos arquivos, encontrou, por vezes na Bélgica e França, lugares propícios para reconstruir suas vidas com algum suporte econômico e social. A estadia em lugares de 'free soil', a experiência de igualdade civil vivida por eles e o contraste enfrentado quando essas pessoas retornam para o sul dos Estados Unidos à beira da Guerra Civil, foram fatores importantes para a 'impaciência' observada entre os 'homens de cor' diante da discriminação racial em estados como a Louisiana (SCOTT \& HÉBRARD, 2014, p. 156). A diferenciação de estatutos metropolitanos e coloniais, bem como a recusa dos países europeus em admitirem e regularem a escravidão em seus próprios territórios, possibilitou a circulação de pessoas libertas, livres de cor, ou mesmo escravizadas,

\footnotetext{
${ }^{7}$ Espanhóis e portugueses estavam há muito em contato com a escravidão de diferentes povos que habitaram as regiões que formariam Espanha e Portugal no processo de fomação de seus estados nacionais ('mouros', povos árabes e africanos, islâmicos).

8 'Men of color'/'people of color' em inglês. O termo 'de cor' fazia referência a um grupo bastante diverso de pessoas não brancas na américa espanhola.

${ }^{9}$ Lugares nos quais estava em vigência o princípio do solo livre.
} 
provenientes dos dois lados do atlântico, que buscaram novas possibilidades de reafirmar ou conquistar suas liberdades constantemente.

Embora boa parte dos governos coloniais tenha tentado - sem sucesso - implementar legislações para o governo dos escravizados (CHAVES MALDONADO, 2011, p.64), não existiu um corpo comum de leis, propriamente escravista, a que pudessem recorrer. Apesar disso, houve uma tradição legal com relação à escravização de homens e mulheres africanas e seus descendentes, tanto na América Portuguesa e posteriormente Império Brasileiro, quanto na América Espanhola (SILVA JÚNIOR, 2013, p.35). O compartilhamento de pressupostos básicos permite localizar, em várias disposições régias, a existência de uma tradição relacionada à escravidão afro-americana (LARA, 2000, p.36). Contudo, as questões legais envolvendo os escravizados, em sua condição ambígua de propriedades e pessoas ${ }^{10}$, eram resolvidas com base, majoritariamente, no direito à propriedade e fontes tradicionais do direito.

A lei de propriedade inglesa, crucial para a constituição de leis escravistas nos Estados Unidos, fornecia categorias legais nas quais os negros poderiam ser encaixados como propriedade e permitia que seus possuidores as utilizassem como bem entendessem. Por isso, aos olhos de legisladores, não havia necessidade de se adotar estatutos específicos (MORRIS, 1996, p.42). No caso hispânico, a tradição jurídica se encontrava dispersa em diversos corpos doutrinários como a "Política" de Aristóteles, as Siete Partidas, a "Política Indiana de Juan" de Solórzano, os chamados códigos negros espanhóis de 1789 (GONZÁLEZ UNDURRAGA, 2021, p.11), a vigência do Corpus Juris Civilis e de leis pragmáticas emitidas pela Coroa. A partir da segunda metade do século XVIII, os Bourbon tentaram legislar a escravidão nas colônias (CHAVES MALDONADO, 2011, p.63). Na América Portuguesa, os principais textos legais referentes aos escravos africanos encontram-se nos livros IV e V das Ordenações Filipinas, que tratavam respectivamente do 'direito civil substantivo, direito das pessoas e coisas sob o ponto

\footnotetext{
${ }^{10}$ Os escravizados eram legalmente considerados coisas, devendo total obediência e subjugação aos senhores; mas, contraditoriamente, eram considerados pessoas e poderiam ser processados e responsabilizados por seus atos caso cometessem crimes. Ver: MACHADO, Crime e Escravidão, 2014.
} 
de vista civil e comercial' e do processo penal. ${ }^{11}$ No Império brasileiro, o tema da escravidão esteve ausente da Constituição de 1824, já no Código Criminal de 1830, os escravos aparecem com penalizações distintas (e mais severas) em comparação aos livres.

\section{Partus sequitur ventrem e os significados da hereditariedade materna da escravidão}

O princípio do partus sequitur ventrem, evocado pelas Partidas espanholas, é oriundo do direito romano e determinava que a condição de nascimento de uma criança dentro de um regime de escravidão deveria seguir a de sua mãe, portanto: mãe cativa, filhos também cativos. Este princípio foi incorporado pelas sociedades escravistas no continente americano ao longo de suas histórias e reforçado em diferentes lugares com o intuito de fortalecer a continuidade do sistema escravista por meio da hereditariedade, mesmo quando a escravidão parecia caminhar para seu fim.

O mundo ibérico, com base nas Siete Partidas, não encontrou empecilhos para adotá-lo integralmente desde a implementação da escravidão em suas primeiras colônias, enquanto as colônias inglesas, por sua vez, demoraram mais para poder firmá-lo como uma regra geral. O princípio, implementado como lei, serviu para ratificar a hereditariedade da condição escrava para africanos e seus descendentes, definida como algo ineludível (MACHADO, 2018, p.334-340). Dessa forma, o partus sequitur ventrem e as disputas travadas ao longo da sua implementação e consolidação da escravidão em sociedades atlânticas são de grande importância para compreender de que forma a mulher negra escravizada (e seu corpo) tornou-se central para a história da escravidão e da abolição. Ou ainda, para compreender como a escravidão foi estruturada com base em categorias de gênero, além de raça.

\footnotetext{
11 Por meio das ordenações Manuelinas e sobretudo das Filipinas, foram fixados os princípios básicos que fundamentaram juridicamente as relações entre senhores e escravos no Brasil colonial. Cada uma delas, indicando e legitimando os fundamentos da escravidão de populações africanas e seus descendentes, serviram, dessa forma, para 'amarrar' os aspetos intrínsecos à escravidão (princípios como compra, venda, doações, necessidade de batismo etc.) Ver: LARA, 2000, p.37.
} 
Por mais que a relação entre a escravidão e o ventre de mulheres escravizadas já estivesse cimentada pelas Partidas nos domínios ibéricos desde o início da colonização, a discussão em torno da reprodução e posse de escravos ganhava importância em momentos de transição e instabilidade do sistema escravista. Particularmente nos territórios hispano-americanos, houve, por parte da coroa espanhola, tentativas de implementar códigos negros para suas colônias em 1768 (Santo Domingo), 1769 (Louisiana) e 1784 (Carolino), todos sem êxito (GRINBERG; PEABODY, 2013, p.70). ${ }^{12}$ Essas tentativas de regulação da escravidão evidenciam a necessidade de se reforçar também a hereditariedade da escravidão, garantindo a reprodução da população escravizada, como veremos a seguir.

Em 1789, uma cédula real espanhola estipulou um conjunto de instruções com o objetivo de assegurar um controle maior sobre os escravizados, que em função do fim do asiento ${ }^{13}$ poderiam ser comprados em larga escala e provenientes de qualquer mercado, causando tensão entre os proprietários. O documento "Instrucción para la educación, trato y ocupaciones de los esclavos" (LUCENA SALMORAL, 2011, p.1150), de caráter paternalista e absolutista, buscava definir e regular as relações entre senhores e escravos, definidas há muito tempo pela legislação romana (CHAVES MALDONADO, 2011, p.65). Constava na Instrução ${ }^{14}$ um código de direitos dos escravizados e normas sobre o tratamento que deveriam receber dos senhores, incluindo regras sobre alimentação, moradia, educação, trabalho, vestuário, saúde, matrimônios etc. Ademais, os senhores deveriam aceitar e incentivar casamentos entre os escravos e por meio de

12 Os três códigos foram inspirados no Code Noir francês. Os códigos negros foram pensados e implementados (ou não) em contextos históricos e geográficos específicos, nos quais se considerou conveniente reforçar a regulação do governo dos cativos. Ver: LUCENA SALMORAL, Op. cit., p.268-275.

${ }^{13}$ Em fevereiro de 1789, o rei Carlos IV havia abolido temporariamente o sistema de asiento (comércio de escravos para os territórios hispânicos na América era monopólio da coroa espanhola, que, a partir de contrato, determinava quem poderia realizá-lo), permitindo que o tráfico de escravos fosse regido pelas leis do livre comércio para os territórios espanhóis. A liberação do tráfico autorizava a introdução de escravos africanos vindos de qualquer mercado.

${ }^{14}$ Em alguns textos é possível encontrar a Instrução nomeada como código negro de 1789. 
melhorias nas condições de vida dos cativos, esperava-se contribuir para a sua reprodução natural (MARTINS, 2017, p.5). ${ }^{15}$

A principal diferença da Instrução de 1789 era de que, ao contrário dos códigos anteriores que permaneceram 'esquecidos' nos arquivos dos conselhos, ela foi distribuída para todo o território hispano-americano. O regulamento provocou uma forte reação entre os proprietários de escravos da América espanhola, sendo que a oposição foi tão forte que, em 1794, os efeitos da legislação foram suspendidos. Apesar disso, María Eugenia Chaves Maldonado afirma que devido à ambiguidade em torno da suspensão do documento, a Instrução não desapareceu da cena judicial e foi rapidamente incorporada ao disperso conjunto de aparatos e discursos jurídicos que eram aplicados nos tribunais coloniais. Essa compilação abriu uma série de possibilidades aproveitadas tanto por escravizados como - contraditoriamente - pelos senhores que a haviam rechaçado (CHAVES MALDONADO, 2011, p.86). Uma mudança fundamental para os cativos foi a figura do procurador de escravos, que adquire relevância nos tribunais, representando escravos litigiantes (CHAVES MALDONADO, 2001, p. 42-43).

A preocupação com a reprodução da população escravizada no mundo hispânico continuou em pauta, explicitada em uma nova cédula real, de abril de 1804 (LUCENA SALMORAL, 2011, p.1197). Esta cédula, além estender o comércio de escravos por mais 12 anos para espanhóis e 6 anos para estrangeiros, determinava o cumprimento escrupuloso das disposições de 1789 e estipulava medidas pró-natalistas muito mais incisivas que as previstas pela Instrução. Umas dessas medidas era de que o governador deveria cuidar para que todos os engenhos providenciassem mulheres escravizadas, e até que todos os homens escravizados estivessem casados, só deveria ser permitida a introdução de escravas do sexo feminino nesses estabelecimentos. A cédula de 1804 evidencia que, com o avanço das discussões sobre o fim do tráfico em diferentes lugares, a coroa espanhola tentava estimular e promover a reprodução

\footnotetext{
15 A ideia de "amelioration" / melhoria nas condições de vida dos cativos será fundamental também nas colônias inglesas do Caribe, como veremos mais adiante. Na verdade, quando a Coroa Espanhola tenta implementar essas melhorias, está seguindo o exemplo das colônias britânicas.
} 
natural da população cativa, como já vinha sendo feito nas colônias britânicas do Caribe desde pelo menos 1790 (MARTINS, 2017, p.7).

$\mathrm{Na}$ América do Norte, antes que o princípio de hereditariedade materna da escravidão fosse consolidado, existiram disputas sobre a taxação do trabalho e gravidez de mulheres que acabaram subsidiando uma crescente diferenciação entre brancos e negros nas colônias inglesas, posteriormente os Estados Unidos. Essas disputas são importantes para compreender a noção de 'trabalho reprodutivo' das mulheres escravizadas. No princípio da colonização inglesa, coexistiram, por um tempo, diferentes formas de trabalho compulsórios, sendo que pessoas brancas compunham boa parte dessa força de trabalho. Nesse cenário, os senhores precisavam pagar um imposto anual referente a cada um de seus trabalhadores empregados - todos os homens livres e pessoas que trabalhassem o solo eram taxadas -, as mulheres que não trabalhavam sob algum contrato foram isentas da taxa porque eram classificadas como sujeitos dependentes financeiramente, carentes de proteção e subordinadas à autoridade dos homens chefes de família.

Conforme a escravidão foi se tornando uma importante forma de trabalho, eventualmente substituindo a servidão de brancos pobres, construções em torno da diferenciação racial forneceram a base legal para a discriminação social entre mulheres brancas e negras (BROWN, 1996, p.108). Como as mulheres africanas já trabalhavam na agricultura antes de serem transportadas para a América, isto foi entendido como uma confirmação de que elas 'naturalmente' serviam para o trabalho nas plantations, em oposição à figura 'frágil' da mulher branca europeia. ${ }^{16}$ Em 1643, a Virgínia ${ }^{17}$ definiu o trabalho de mulheres africanas escravizadas como taxável, classificando-as necessariamente como trabalhadoras do campo e equiparando seu

\footnotetext{
${ }^{16}$ Falamos aqui de construções sociais em torno do que seria considerado feminino à época e da oposição criada entre mulheres brancas e negras. A consolidação da ideia de feminilidade é, essencialmente, atrelada à figura da mulher branca europeia. Segundo Kathleen M. Brown, os debates em torno da natureza da mulher ao longo do século XV na Inglaterra e outros países europeus serviram para construir, sob a alegação da fraqueza física e moral feminina, uma metáfora para a suposta 'natural' submissão das mulheres aos homens. Ver: BROWN, 1996, p.15-17

${ }^{17}$ A Virgínia era um dos estados mais importantes das 13 colônias e dos Estados Unidos independente. Por isso, servia de modelo para os demais estados, que seguiam suas decisões.
} 
trabalho àquele executado por homens. ${ }^{18}$ Quando a lei taxou o trabalho de mulheres africanas - e posteriormente o de mulheres libertas também, mas isentou mulheres brancas de tal ato, criou-se uma distinção legal entre mulheres brancas e negras (BROWN, 1996, p.116).

Neste cenário, quando uma trabalhadora contratada engravidava, era habitual que o senhor pedisse isenção de impostos em função da perda momentânea de sua força produtiva e adicionava-se um período extra ao contrato de trabalho. Em relação às mulheres escravizadas, não era possível estender o contrato já que elas trabalhariam por toda a vida. A forma encontrada para compensar o proprietário foi presumir que os filhos das escravizadas deveriam ficar com os proprietários de suas mães, ligando assim a reprodução da mulher escravizada (seus filhos) ao trabalho (BROWN, 1996; MACHADO, 20108b). A partir dessas decisões legais sobre o trabalho produtivo e reprodutivo de mulheres, a diferenciação racial foi se estreitando cada vez mais com noções de feminilidade que vinham sendo construídas. A herança materna da escravidão impulsionou a ideia de que esta seria uma condição natural dos africanos e seus descendentes.

Pouco tempo depois seria criado, também na Virgínia, o primeiro estatuto com a intenção de regular relações sexuais entre pessoas de diferentes 'raças', o qual pretendia responder aos questionamentos em relação à paternidade branca/europeia: "o filho de um homem inglês com uma mulher negra deveria ser considerado escravo ou livre?” (MORGAN, 2018, p.1-2). Em resposta, a decisão tomada pelo estado da Virgínia: "promulgada e declarada por esta grande assembleia, todas as crianças nascidas neste país devem ser consideradas livres ou escravas de acordo com a condição de suas mães" (MORGAN, 2018, p.1-2). Além de ser responsável por cimentar de vez a hereditariedade materna da escravidão, o estatuto de 1662 evidencia como o perigo da miscigenação, fruto das relações inter-raciais, e a proteção da propriedade senhorial estiveram no centro dos debates sobre a escravidão. ${ }^{19}$

\footnotetext{
${ }^{18}$ Segundo bell hooks, a dinâmica da opressão sexista e racista durante a escravidão deveria ser estudada à luz do comportamento de masculinização de mulheres negras. Isso porque, afora mulheres brancas forçadas a trabalharem no campo como castigo por delitos, esse era um trabalho indigno do título "mulher". E apesar de ser um trabalho comum para mulheres na África, as africanas logo perceberam que nessa outra sociedade esse era um trabalho masculino e que elas eram vistas como substituição de homens. Ver: hooks, bell. E eu não sou uma mulher?, 2020, p.48

${ }^{19}$ Tanto no caso inglês quanto no francês é possível identificar a miscigenação enquanto problema e risco para a manutenção da propriedade escravista. A paternidade branca/europeia levanta questões sobre qual deveria ser o
} 
Apesar de supostamente procurar responder uma questão mais ampla sobre as relações entre pessoas de diferentes cores e 'raças', a pergunta foi formulada de forma bem específica e as personagens desse provável encontro sexual foram precisamente determinadas. Além de envolver pessoas de diferentes 'raças', o status legal e a condição social do possível 'casal' também entrou na equação, permitindo-nos supor que a maior parte desses 'encontros' sexuais acontecessem com mais frequência entre homens brancos e mulheres negras, refletindo uma relação de poder, pautada no gênero, característica do sistema escravista (PASSARINI SOUSA, 2021b, p.26). Além de racializada, a resolução tomada é sintomática da desvalorização sofrida pelo sexo feminino, sentida de maneiras diferentes por mulheres brancas e negras, tanto na questão da reprodução como na do trabalho.

Por outro lado, o envolvimento de uma mulher branca com um homem negro (escravizado ou livre) deveria ser punido com uma multa, sendo que caso a mulher envolvida não tivesse condições para pagá-la, deveria ser obrigada a trabalhar como serva por cinco anos. Os filhos dessa relação, por sua vez, precisariam trabalhar como servos até que completassem trinta e um anos de idade, independentemente da punição sofrida por suas mães. ${ }^{20}$ Mães e filhos foram duramente punidos pela lei nas diferentes configurações possíveis de relações inter-raciais. 21 Para Jennifer Morgan, ao declarar crianças nascidas de mulheres negras como escravas independentemente da condição do pai, a decisão do Estado da Virgínia - que se constitui o núcleo da legislação para os estados sulistas - cimentou a associação entre negritude e o trabalho

status das crianças (filhos). Nesse sentido, além de conservar a propriedade escrava, estes estatutos - principalmente o aprovado pela Virgínia - tinham como objetivo regular e proibir relações inter-raciais. Mas a implementação do partus sequitur ventrem, ao conservar o direito de propriedade, pouco faz para coibir relações sexuais e o estupro por parte de homens brancos sobre mulheres negras.

${ }^{20}$ No fim do período colonial, surge um desconforto em colocar sob regime de servidão os filhos de mulheres brancas livres com homens negros e/ou escravizados e, por isso, ao longo do século XIX o tempo de serviço (até 30 anos) para os filhos de mulheres brancas vai sendo reduzido. MORRIS, Thomas. Southern Slavery and the Law, 1996, p.22-24

${ }^{21}$ No entanto, se no século XIX o período de servidão dos filhos de mulheres brancas livres com homens negros foi reduzido, devido a questões 'humanitárias' que surgiam, os filhos de mulheres negras escravizadas com homens brancos não foram alvo de qualquer sensibilização e continuaram a ser legalmente escravos. 
forçado, ${ }^{22}$ estabelecendo por lei a hereditariedade da escravidão (MORGAN, 2004, p.72). O ato de 1662 conectou explicitamente hereditariedade com raça. A perspectiva pela qual os homens brancos das elites pensaram a existência de crianças miscigenadas tornou-se crucial para a adoção do princípio do partus sequitur ventrem. Os filhos das mulheres escravizadas foram considerados como fruto do crescimento da propriedade do senhor, uma extensão de suas mães e, por consequência, também colocados como propriedades, sobre as quais os proprietários detiveram plenos direitos.

Segundo Jennifer L. Morgan, proprietários e legisladores da Virgínia recusaram-se - ou falharam - em explicar o princípio da matrilinearidade como um elemento fundante do status legal das crianças, deixando a questão fundamental (da lógica usada para escravizar) sem respostas. Para a autora, essa lacuna estabeleceu um problema crucial tanto para a conformação de estudos na área da escravidão quanto para a história de gênero (MORGAN, 2018, p.5). No contexto escravista do Novo Mundo, a maternidade tornou-se o veículo pelo qual os significados raciais acabaram se concretizando: foi por meio do ventre de mulheres negras africanas e de suas descendentes que a escravidão foi sendo passada por séculos. Enquanto por muito tempo os homens reclamaram para si o poder sobre a descendência e controle das heranças familiares no mundo branco e livre, ao se defrontarem com a escravidão, inverteram esse processo, preservando mais uma vez seu poder econômico e social (MORGAN, 2018, p.12). Reafirma-se assim o poder de brancos sobre negros e, mais especificamente, de homens brancos sobre mulheres negras.

Para a historiadora Camillia Cowling, o princípio do partus sequitur ventrem teria funcionado como cerne da diferenciação imposta entre populações livres e escravizadas. Enquanto entre pessoas brancas e livres a condição legal dos filhos era fornecida pelo pai, entre a população escravizada a herança da escravidão estava atrelada à condição da mãe, sem importar o status legal do pai da criança (COWLING, 2018, p.110). Essa espécie de inversão, imposta

\footnotetext{
${ }^{22}$ Em legislações anteriores, como no estado de Maryland, em 1643, a diferença entre mulheres brancas servas da Coroa Inglesa na colônia e mulheres negras escravizadas consistia na sua relação com o trabalho. $\mathrm{O}$ trabalho de mulheres negras foi definido como permanente, associando sua cor ao trabalho forçado. Ver: MORGAN, 2004, p.72.
} 
pela adoção do princípio romano nas sociedades escravistas atlânticas, pode ser compreendida como um reforço do poder patriarcal dos senhores de escravos, tanto em relação à parcela livre da população a ele subordinada quanto aos escravizados, fossem eles homens ou mulheres. A hereditariedade do cativeiro pela via materna interferiu diretamente nas experiências de cativeiro, diferenciadas, para homens e mulheres. Os homens escravizados foram excluídos da constituição de um vínculo formal com possíveis filhos, já que na maioria dos casos apenas o status das mães ficava registrado no documento de batismo, por ser esta a informação definidora da condição dos rebentos.

Para as mulheres escravizadas, a questão da matrilineridade da escravidão teve consequências específicas, como o abuso sexual. O estupro de mulheres escravizadas, hoje amplamente reconhecido pela historiografia, foi parte fundamental ao exercício do poder escravista: "as mulheres sofriam de forma diferente, eram vítimas de abuso sexual e outros maus-tratos bárbaros que só poderiam ser infligidos a elas (...) podiam ser exploradas, punidas e reprimidas de modos cabíveis apenas às mulheres" (DAVIS, 2016, p.19). Atrelar a escravidão à maternidade de mulheres escravizadas significou legitimar o abuso sofrido por elas, uma vez que a despeito de possíveis abusos, os proprietários não só mantiveram seus direitos de propriedade sobre as mulheres como adquiriram direitos sobre as crianças. Existiram casos em que pais eram proprietários dos próprios filhos, porque não havia um código legal que proibisse essas situações. Devido a uma série de estereótipos e representações sobre as populações africanas (MORGAN, 2004), mulheres negras (africanas ou afro-americanas, escravizadas ou libertas) não eram consideradas mulheres que precisavam de proteção, segundo concepções construídas ao longo dos séculos XVI e XVIII, e por isso foram excluídas de leis relativas ao estupro.

Os diferentes mecanismos usados para garantir a herança/hereditariedade da escravidão evidenciam como a lei nada tinha de natural, era fruto de uma necessidade, e se adequou a realidades específicas encontradas nas Américas. A legislação foi um mecanismo importante para dar continuidade ao cativeiro. O partus sequitur ventrem acabou, em última análise, legitimando o estupro sistemático de mulheres escravizadas, uma vez que, como propriedades de 
outrem, elas não poderiam, legalmente falando, ser estupradas. ${ }^{23}$ A falta de punições por parte da lei e a certeza de que os filhos dessas mulheres também seriam propriedades, fez com que, juntos, esses dois elementos (partus sequitur ventrem e estupro) fossem garantidores da reprodução da escravidão - a reprodução natural e das estruturas de poder.

O partus sequitur ventrem, independentemente de ter sido aplicado prontamente, como no mundo ibérico, ou com o passar do tempo - na América inglesa, foi o mecanismo que realçou a diferenciação de sexo entre a população escravizada, exercendo influência direta sobre a construção das sociedades em territórios americanos. Ele atravessou o cotidiano da escravidão de diferentes maneiras: os problemas da formação da família escrava, sua permanência ou separação dentro regime escravista, o abuso de homens brancos proprietários sobre mulheres escravizadas, as possibilidades de as mulheres cativas construírem relações amorosas, o significado que a maternidade pode ter adquirido sob a escravidão, qual o impacto sobre a mulheres escravizadas tanto da maternidade quanto da condição passada aos filhos, de que forma isso pode ter influenciado as suas buscas pela autonomia de seus corpos, se elas recusaram a maternidade e de que forma o fizeram, as influências sobre decisões drásticas como aborto e infanticídio, bem como seus projetos de família e liberdade.

As mulheres desenvolveram, nesse sentido, uma relação diferenciada com a lei, o que pode ser entendido como fruto da própria diferenciação de gênero dos escravizados no regime escravista. Segundo Camillia Cowling, a oposição entre a pequena presença feminina escrava em processos criminais, quando comparada à recorrência de homens, e a sólida participação delas em processos civis, sugerem diferentes estratégias de homens e mulheres para lidarem com a escravidão. Enquanto os homens recorriam majoritariamente a meios extralegais, as mulheres buscavam agir dentro das possibilidades da lei (COWLING, 2018, p. 103-104). O partus sequitur ventrem pode estar no centro disso. Talvez essa propensão aconteça justamente pelos

\footnotetext{
${ }^{23}$ No sul dos Estados Unidos, por exemplo, as mulheres negras foram excluídas da legislação relativa ao crime de estupro. Ver: BLOCK, 2006. Já no Brasil, o código penal de 1830 do Império caracteriza o estupro como um ato contra a "mulher honesta", omitindo qualquer menção à mulheres escravas ou negras. O estupro se constitui uma dimensão importante da centralidade do corpo feminino como lócus de existência da própria escravidão. Ver: PASSARINI SOUSA, 2021b, p.42-45.
} 
laços com os filhos, muitas mulheres entraram na justiça para alforriar seus filhos. É possível discutir também o porquê das mulheres não fugirem na mesma proporção ou com mesma facilidade e frequência que os homens. O que as impedia? Além de estarem, proporcionalmente, em maior número no serviço doméstico, o que implicava proximidade e maior controle dos proprietários, a possibilidade de ter que deixar filhos para trás pode ter influenciado suas ações para conseguir a liberdade nos termos da lei. Em todos os lugares onde houve escravidão, as mulheres foram mais alforriadas que os homens ${ }^{24}$ (GRINBERG; PEABODY, 2013, p.16).

É importante sublinhar também que apesar da implementação do partus por todo o continente americano, existiram tradições jurídicas e arcabouços legais distintos, sobretudo em uma comparação entre sociedades ibéricas e anglófonas. Embora as alforrias não fossem uma prerrogativa exclusiva de regiões de colonização espanhola ou portuguesa, as legislações dessas regiões (América Latina, Cuba e Brasil) estavam baseadas nas Siete Partidas, que além de reconhecerem a liberdade como uma condição natural, previam várias possibilidades de obtenção de alforria, como, por exemplo, pagar pela liberdade, casar-se com uma pessoa livre, coartação ${ }^{25}$, probabilidades expressas no título 22 da Quarta Partida (GRINBERG; PEABODY, 2013, p.68). Por mais que as provisões não fossem garantias de alívio das condições do cativeiro para os escravizados, as alforrias foram uma tradição do mundo ibérico e as mulheres escravizadas foram protagonistas tanto na obtenção da alforria quanto nas disputas judiciais para obterem a liberdade.

Desta forma, acredito que um olhar mais atento e cuidadoso para o princípio do partus sequitur ventrem é imprescindível para que se compreendam as bases em que os sistemas escravistas foram construídos, bem como os modos pelos quais a escravidão se perpetuou: por meio de concepções raciais e de gênero que influenciaram a forma como as mulheres escravizadas viveram a escravidão. Este princípio legal abre as portas para uma análise da escravidão sob uma perspectiva de gênero, compreendendo esta como uma categoria estruturante

\footnotetext{
${ }^{24}$ Com exceção dos Estados Unidos, onde os números eram equivalentes. Ver: GRINBERG; PEABODY, 2013

${ }^{25}$ Mecanismo segundo o qual o escravizado ou a escravizada poderia comprar sua liberdade em prestações. Eram os coartados na América espanhola e statuliber no Brasil. Na América espanhola, a coartação foi a principal forma de obtenção de alforria. Para saber mais sobre a coartação, ver: GRINBERG; PEABODY, 2013, p.72-76
} 
das relações sociais (SCOTT, 1990). Como apontou Maria Helena P.T. Machado, já não cabe mais tratar os processos intrínsecos ao cativeiro sob uma perspectiva que trata de escravos, de maneira genérica, escamoteando as experiências de mulheres escravizadas, marcadas pela condição de sua raça e gênero dentro dessas sociedades (MACHADO, 2018, p.334). Raça e gênero entremeiam-se, consolidando diferentes maneiras de apreender a experiência da escravidão, liberdade, família, maternidade, trabalho e reprodução.

\section{Gênero e reprodução na era da abolição: políticas pró-natalistas e leis de ventre livre}

A partir da segunda metade do século XVIII, há uma mudança considerável nos discursos relativos à escravidão, nos quais preceitos humanitários e morais passam a ser evocados em favor dos escravizados. A partir deste momento, a instituição escravista foi paulatinamente compreendida como algo imoral e atacada pelo movimento abolicionista. Nesta perspectiva, o tráfico de escravos representava o ápice da imoralidade da escravidão porque era tido como um estímulo à crueldade e violência de senhores e feitores que, em face do fornecimento abundante de mão de obra, desvalorizavam a vida dos escravizados. O fechamento do tráfico era, portanto, o primeiro passo para acabar com a escravidão e obedeceu a contextos específicos de cada lugar. Para se ter uma ideia, em 1808 ele já havia sido abolido para os Estados Unidos e possessões inglesas na América, enquanto só foi encerrado definitivamente para o Brasil em 1850, e na década de 1860 para Cuba.

A conjuntura de fechamento do tráfico é importante para compreender de que maneira diferentes sociedades escravistas procuraram lidar com a questão do fornecimento de mão de obra, e como isto se ligou intimamente com a realidade vivida por mulheres escravizadas em diferentes lugares da América. Se antes, por praticamente três séculos, o tráfico havia abastecido diversos lugares com trabalhadores e trabalhadoras escravizadas, no último terço do século XVIII, um quadro de massiva propaganda abolicionista se apresentou como uma ameaça real à escravidão e ao tráfico. O problema principal era, por um lado, a necessidade de manter a 
produtividade do trabalho escravizado e, por outro, encaminhar o fim da escravidão, condenável e desumana.

A preocupação dos políticos - abolicionistas ou não - nas primeiras discussões sobre o fim do tráfico, ocorridas na Inglaterra, era garantir que as colônias não sofressem um golpe que afetasse a produção por falta de mão de obra. Por isso, todos defendiam uma saída gradual para a escravidão. Com o fim do tráfico, a reprodução natural dos cativos foi a saída pensada para evitar um colapso econômico. Assim, a habilidade reprodutiva das mulheres escravizadas se apresentou como uma solução porque permitia acabar com o tráfico, enquanto procurava-se manter o fluxo de mão de obra pelo crescimento natural da população (PASSARINI SOUSA, TARDIVO, HAACK, 2021, p.65). A reprodução oferecia, assim, uma chance de estabilidade para proprietários de escravos, ao mesmo tempo em que respondia inicialmente aos apelos dos abolicionistas, algo que Sasha Turner avaliou como "o paradoxo da busca abolicionista para salvar as vítimas infelizes do tráfico de escravos, mas não sem garantir que as plantações de açúcar mantivessem sua produtividade” (TURNER, 2017, p.4).

Desta forma, as mulheres escravizadas (seu corpo, sexualidade, maternidade, gravidez) estiveram no centro dos primeiros debates sobre o encaminhamento da questão da escravidão, encabeçado pela Inglaterra. Nesse sentido, elas foram centrais tanto para a propaganda do abolicionismo quanto para uma nova política colonial a ser implementada. O movimento abolicionista buscava provar que a escravidão agredia não só os corpos das mulheres escravizadas, mas também debilitava sua moral. Além de serem abusadas sexualmente e impedidas de se casarem dentro dos preceitos da religião, o regime escravista lhes reservava dietas inadequadas, um regime de trabalho extenuante e punições físicas severas, que não eram aliviadas mesmo quando elas engravidavam (TURNER, 2017, p.45). Essa degradação moral sofrida, por sua vez, impedia as mulheres escravizadas de cumprirem devidamente com seus 'papeis femininos ${ }^{26}$, prejudicando também, em consequência, sua fertilidade.

\footnotetext{
${ }^{26}$ Quando falamos de papéis femininos ou características tipicamente femininas estamos nos reportando sempre aos discursos e representações que procuravam definir os comportamentos das mulheres na sociedade desde meados do século XVII. As concepções sobre os 'papéis femininos' estão inseridas no chamado 'culto da verdadeira feminilidade' ('cult of true womanhood'), uma ideologia que buscava definir o que era aceitável para o
} 
O abolicionismo, enquanto movimento social, se colocou como uma causa humanitária, ligada à compaixão e sentimento. Os atributos morais com os quais o compromisso abolicionista pretendia se identificar foram, desde o início, relacionados a uma suposta 'natureza feminina'. Nesse sentido, a 'natureza feminina' era desenhada dentro da ideologia das esferas separadas, na qual o mundo público, caracterizado pela razão e espaço da política, reservado aos homens, e o lar, lugar dos sentimentos e cuidados com os outros, era território feminino por excelência (WELTER, 1966, p.151). Os ideais de feminilidade e domesticidade foram cruciais para que as mulheres escravizadas passassem a ser representadas como mães e esposas, cujos 'direitos femininos' haviam sido negados pelo sistema escravista. ${ }^{27}$ Nesse sentido, buscava-se criar uma correspondência entre a mulher escrava e a emergente "representação da mãe burguesa" que “carregava em si o ideal do devir feminino, biologicamente determinado” (ARIZA, 2017, p.46)

Tanto o abolicionismo quanto a política colonial britânica se apropriaram desses ideais de feminilidade, domesticidade e maternidade, pleiteados como 'direitos' por abolicionistas brancas em prol das mulheres escravizadas nas colônias e os manejaram de acordo com seus interesses. O ponto principal era melhorar as condições de vida da população escravizada (política de amelioration) e 'prepará-la' para a abolição completa. Nesse sentido, era preciso primeiro restaurar a moralidade feminina, isso significava melhorar a vida das mulheres escravizadas para estimulá-las a formarem famílias, possibilitando que elas cumprissem seus 'papéis femininos', de esposas e mães. O objetivo era de que essas mulheres fornecessem mão de obra, a qual não seria mais reposta pelo tráfico.

$\mathrm{Na}$ década de 1780, os abolicionistas propuseram a melhoria das condições médicas e materiais de jovens mulheres escravizadas. Equiparar a população escrava feminina e masculina, bem como promover relações monogâmicas entre os cativos eram pontos centrais desses projetos

comportamento de 'mulheres de verdade'. Os 'atributos' da 'verdadeira feminilidade' eram aqueles pelos quais as mulheres julgavam a si mesmas, eram julgadas por seus maridos, familiares e pela sociedade de modo geral, sendo divididos em quatro virtudes 'principais': piedade, pureza, submissão e domesticidade. A mulher que fosse portadora de tais virtudes, teria a promessa de felicidade completa. Ver: WELTER, 1966.

${ }^{27}$ Discuto a importância do gênero na organização do abolicionismo de raiz britânica e norte-americana e de que maneira a mulher escravizada acabou sendo colocada no centro do processo emancipatório por esse discurso no terceiro capítulo de minha dissertação de mestrado. Ver: PASSARINI SOUSA, 2021b, p. 89-128. 
que tinham como objetivo principal resolver o problema da fertilidade feminina e a baixa taxa de nascimentos na região (BUSH, 1996; ALTINK, 2002; TURNER, 2017, p.19-20). ${ }^{28}$ O abolicionismo inglês alçou, assim, as mulheres negras escravizadas ao centro de uma política ainda colonial, mas que se voltava à abolição gradual da escravidão.

Nas colônias britânicas do Caribe, as mulheres escravizadas dominavam o trabalho no campo e ultrapassavam em muito o número de homens na lavoura, isso acontecia porque além de estarem em menor número, eles eram alocados em uma diversidade muito maior de trabalhos especializados (ALTINK, 2002, p.19). As escravizadas que trabalhavam no eito eram as trabalhadoras mais saudáveis, mais férteis e que por isso aquelas que tinham mais chances de engravidar, extremamente importantes e altamente produtivas (TURNER, 2017, p.73-74). Por isso, quando os abolicionistas passaram a requisitar melhorias nas condições de vida principalmente das mulheres escravizadas, encontraram grande resistência dos proprietários que se recusavam a perder, mesmo que momentaneamente, parte de sua força de trabalho nas plantations para adotar medidas em favor da reprodução, gravidez e cuidados neonatais.

A partir desse momento, a reprodução, e principalmente a baixa taxa de fertilidade entre as escravizadas no Caribe inglês, se tornou questão central para os embates entre abolicionistas e colonialistas. $^{29}$ Mesmo de lados 'opostos', ambos procuravam solucionar o problema da fertilidade; com objetivos diferentes, escravistas e abolicionistas concordavam que estimular a reprodução era a solução naquele momento. Contudo, havia diferentes visões sobre as causas da baixa fertilidade e quais estratégias utilizar para controlar o trabalho reprodutivo de mulheres escravizadas. Para os abolicionistas, as mulheres escravizadas apresentavam baixas taxas de fertilidade pelas condições materiais e morais da própria escravidão: jornadas de trabalho exaustivas, alimentação inadequada, condições muito precárias de saúde, castigos físicos

28 A tentativa da Coroa Espanhola em equiparar a população escrava feminina e masculina, mencionada anteriormente, espelhava-se diretamente nas políticas implementadas no Caribe Inglês nas últimas décadas do século XVIII.

${ }^{29}$ É preciso lembrar que as colônias inglesas no Caribe (ao contrário de lugares como Brasil e Estados Unidos, por exemplo) tinham como característica proprietários absenteístas, ou seja, proprietários que residiam na metrópole e deixavam a administração do cotidiano das propriedades nas mãos de funcionários. Isso também acarretou inúmeros conflitos entre proprietários e administradores, que muitas vezes não concordavam com as políticas aprovadas na metrópole e resistiam o quanto podiam para implementá-las. 
constantes etc. Por sua vez, os senhores de escravos culpavam a 'inferioridade' e 'imoralidade' das práticas culturais dos cativos e, segundo eles, a 'promiscuidade' das mulheres escravizadas e doenças venéreas eram as principais responsáveis pelo fracasso da reprodução entre os escravos no Caribe (BUSH, 1996, p.201-202).

Embora denunciassem os males da escravidão, os abolicionistas não eram contrários à política imperial inglesa e, por isso, a promoção de políticas pro-natalistas dentro de um projeto maior de emancipação gradual os permitia conectar objetivos abolicionistas com um processo de reforma e civilização da população negra que servia ao império britânico, tudo isso por intermédio do corpo e da reprodução de mulheres escravizadas. Nesse sentido, provar que a falta de civilização (inferioridade) das populações escravizadas (africanas e afro-americanas) era consequência das condições de vida forjadas pela escravidão era o objetivo dos abolicionistas. ${ }^{30}$ Para os escravistas, essa era uma questão biológica e cultural.

Para William Wilberforce, famoso abolicionista britânico, forjar laços familiares e construir comunidades eram as melhores maneiras de reforçar a reprodutividade entre as mulheres cativas, seu plano incluía casamento e moradias independentes para os casais. Segundo ele, se os senhores garantissem às mulheres um 'santuário doméstico', a ternura maternal, simpatia doméstica e interesses paternos apareceriam, ademais, quando as escravizadas tivessem uma casa onde as crianças pudessem nascer com segurança, a concepção e gravidez aconteceriam. Além disso, Wilbeforce defendia algumas indulgências às mães, como um tempo de manhã e à tarde para cuidar dos filhos, as quais, segundo ele, estimulariam a afeição doméstica feminina (WILBERFORCE apud TURNER, p.2). ${ }^{31}$ Legislações destinadas a melhorar o bem-estar das mulheres escravizadas e promover o crescimento saudável da população foram introduzidas a partir de $1790^{32}$ nas colônias do Caribe inglês. Mas desde a década de 1780, com a

\footnotetext{
${ }^{30}$ Mesmo entre abolicionistas a inferioridade de africanos e escravizados não era questionada, era um fato. A questão era identificar as causas dessa suposta inferioridade.

${ }^{31}$ A domesticidade e a maternidade eram pilares das construções sobre a feminilidade que estavam em voga na metrópole. Ver WELTER, 1966.

32 A "Slave Law", aprovada em dezembro de 1788, na Jamaica, foi a primeira a conter cláusulas protetivas especificamente destinadas às mulheres escravizadas. Ela estipulava que os administradores das propriedades deveriam receber recompensas monetárias para cada nascimento entre os escravizados, deste modo, supunha-se que a proteção das cativas grávidas estava sendo encorajada. Ver: Altink, 2002, p.18;
} 
iminência do fim do tráfico, alguns proprietários passaram a fornecer recompensas materiais para mulheres que dessem a luz. ${ }^{33}$ Os senhores usavam essas medidas como uma forma de rebater a crítica abolicionista, mostrar que eram bons senhores, e que a escravidão não era tão cruel como o abolicionismo a representava (ALTINK, 2002, p.37).

Em 1792, a política de recompensa se tornou lei na Jamaica, estipulando que propriedades que mostrassem o crescimento natural da população escravizada deveriam pagar uma quantia para o administrador, que deveria ser dividida igualmente entre a mãe e a parteira (ALTINK, 2002, p.37-38). ${ }^{34}$ Ainda em 1792, a cláusula XXXVI da "Slave Law” declarava que todas as mães que tivessem seis filhos vivos deveriam ser retiradas do trabalho no campo, e seus proprietários ficariam isentos de pagar taxas relativas a essas trabalhadoras (ALTINK, 2002, p.39; BUSH, 1996, p.199). Em 1798, outra legislação determinou que mulheres grávidas de 5 meses deveriam ser empregadas em trabalhos leves e deveriam ser construídos quartos para cada mulher grávida do primeiro filho. Em 1823, o açoitamento de mulheres foi proibido em Trinidade e em 1833 a Lei de Emancipação (Slavery Abolition Act - cláusula XVII) proibiu o açoitamento feminino nas demais colônias (BUSH, 1996, p.197). ${ }^{35}$

A coroa espanhola também tentou promover a reprodução natural da população escrava, em consonância com o que vinha sendo proposto para as colônias britânicas do Caribe desde 1780, mas sempre encontrou resistência. ${ }^{36} \mathrm{O}$ exemplo inglês chegou a ser mencionado em discussões, tanto por aqueles que defendiam modelo similar, quanto pelos proprietários que se opunham à proposta. Particularmente entre os senhores de escravos cubanos, as propostas geraram alvoroço, eles rejeitavam firmemente a ideia de promoverem melhorias no tratamento dos escravos (MARTINS, 2017, p.8) sob a justificativa de uma suposta 'brandura' do sistema cubano em comparação ao britânico.

\footnotetext{
${ }^{33}$ Rum, roupas para os bebês, porções extra de comida. Alguns davam joias e roupas. Ver: ALTINK, 2002, p.36-37

${ }^{34}$ Essa medida foi revogada em 1827, sob a justificativa de que era uma fonte de "inveja" e conflito por parte de mulheres que perdiam suas crianças antes do tempo estipulado para serem recompensadas, em relação às companheiras de cativeiro que haviam sido pagas (ALTINK, 2002, p.37).

${ }^{35}$ Slavery Abolition Act (1833). Parliament of the United Kingdom. Session in 28th August. 1833. Disponível em: $<\underline{\text { https://www.pdavis.nl/Legis 07.htm }>}$

${ }^{36}$ Existiram discussões sobre a questão nas Cortes de Cádiz em 1811 e em Cortes Extraordinárias, para além da Instrução e Cédula Real de 1804, ambos já mencionados anteriormente.
} 
temos tantos livres, que podemos demonstrar por todos os meios a geral doçura de nossos costumes a esse respeito, e as vantagens que colhem os negros transportados e colocados nas nossas mãos, não precisamos imitar a conduta de outras nações (...) os ingleses tem a metade dos negros que importam (PARREÑO apud MARTINS, 2017, p.8) [grifo nosso]

No Brasil, em 1823, José Bonifácio propôs na "Representação a Assembleia Geral Constituinte e Legislativa do Império do Brasil sobre a Escravatura" medidas para acabar gradualmente com a escravidão, dentre as quais havia um conjunto de propostas destinadas especificamente às mulheres escravizadas. ${ }^{37}$ Para consolidar uma nova sociedade (o Império, recém independente de Portugal), o autor apresenta disposições acerca da mulher, seu trabalho, gravidez, filhos, reprodução, relações sexuais e afetivas, em moldes similares aos discutidos por abolicionistas ingleses. Seu projeto permite identificar a centralidade que a mulher negra escravizada, e depois liberta, adquire dentro de uma sociedade que transita entre a escravidão e o mundo livre. As conexões entre propostas de diferentes lugares evidenciam como havia uma circulação de ideias relativas à escravidão e abolição pelo mundo atlântico (PASSARINI SOUSA, 2020, p.187-188).

As 'melhorias' na vida das mulheres cativas, propostas por abolicionistas, iam desde o estímulo ao casamento entre escravizados (institucionalização das uniões), tempos de descanso no trabalho, trabalhos leves e até isenção do trabalho enquanto estivessem grávidas, tempo de recuperação após o parto, tempo adequado de amamentação dos filhos, liberdade como recompensa 'final' aos serviços prestados - a depender da quantidade de fillhos que tivessem. Ainda assim, permanece a questão: como controlar aspectos tão íntimos da vida de uma pessoa? Diante disso, o cotidiano das mulheres escravizadas foi afetado. Antes, os proprietários eram indiferentes às questões de reprodução e natalidade e essas mulheres se aproveitavam disso para construir uma certa autonomia sobre os aspectos íntimos de suas vidas como a gravidez, rituais de parto e cuidados neonatais. Por isso, além da disputa sobre a reforma no plano ideológico, pensada por abolicionistas, e as implementações práticas dos proprietários, havia também o conflito com as concepções das próprias mulheres escravizadas sobre seus corpos e costumes.

${ }^{37}$ A Constituinte de 1823 foi dissolvida por D. Pedro I, e a Representação de Bonifácio não chegou a ser apresentada. Ela foi publicada posteriormente, enquanto ele estava exilado na França. 
O estudo de Sasha Tuner evidencia como as mulheres escravizadas colocaram dificuldades aos proprietários e à mudança que eles impunham às suas práticas, refletindo um conflito mais amplo entre essas mulheres, os proprietários, e os abolicionistas (TURNER, 2017). Cada vez mais, o que era dominado por um saber ancestral africano e feminino, marcado por rituais simbólicos, foi sendo tensionado e substituído por um conhecimento branco e masculino sobre ginecologia, partos, amamentação e cuidados com os recém nascidos. Neste novo contexto, muitos homens europeus migraram para as colônias com o objetivo de praticar medicina com os escravizados. Essa era também uma disputa de poder sobre um conhecimento reprodutivo/ginecológico - que até o século XVIII era visto como domínio das mulheres (PAUGH, 2017, p.89). O crescimento natural da população caribenha só aconteceu após a abolição definitiva da escravidão, em 1838, evidenciando o fracasso das políticas pró-natalistas (BUSH, 1996, p.209). A política colonial britânica é importante porque informa e consolida concepções acerca da maternidade escrava e sobre a condução do processo de abolição, as políticas de estímulo à reprodução implementadas eram uma forma de regular a vida das mulheres escravizadas em nome do processo de emancipação.

Em concomitância com a efervescência dos debates abolicionistas e políticas coloniais da Inglaterra no Caribe, outros lugares da América passaram a se debruçar sobre o problema da escravidão, optando por políticas que também incidiram diretamente sobre o corpo feminino negro. As chamadas 'leis de ventre livre' buscaram interromper a hereditariedade da escravidão. Embora os caminhos fossem diferentes, o gênero e a mulher escravizada foram centrais para o encaminhamento da abolição no continente americano. Os estados do norte dos Estados Unidos foram os primeiros a aprovarem leis que libertavam, gradualmente, as gerações futuras, seguidos pelos países da América Latina, que lutavam pela independência da coroa espanhola. Em ambos os casos, a participação de contingentes negros - escravizados ou libertos - nos exércitos foi fundamental para o desenrolar dos conflitos, o que, de modo geral, fortaleceu o poder de barganha e possibilitou fugas, enfraquecendo a escravidão. Para o caso da América Latina, George Andrews afirma que o preço dessa participação foram os programas de emancipação gradual espalhados pela América (ANDREWS, 2014, p.88). 
Entre 1780 e 1804, Pensilvânia, Connecticut, Rhode Island, Upper Canada, Nova York e Nova Jersey foram responsáveis por aprovarem e implementarem as primeiras leis de ventre livre do continente americano. Essas experiências acabaram definindo uma base comum que seria usada posteriormente em diversas libertações do ventre escravizado e que acabaram por se disseminarem pelo Atlântico, desembocando no caso brasileiro, último deles quase um século mais tarde (PASSARINI SOUSA, 2021a). Ainda na primeira metade do século XIX, os países da América hispânica continental seguiram caminho semelhante ao dos estados do norte dos Estados Unidos. De 1811 a 1842, Chile, Argentina, Colômbia, Peru, Uruguai, Bolívia e Paraguai também aprovaram Leis de Ventre Livre.

As "post nati acts" (norte dos EUA) e "leyes de libertad de vientres" (América Latina) declaravam livres os filhos de mulheres escravizadas, com um período obrigatório de serviços a serem prestados por estas crianças aos senhores de suas mães, geralmente em torno de 20 anos. Embora não fossem sociedades que dependessem inteiramente do trabalho escravo - como Brasil, Cuba e sul dos EUA - tanto os estados do norte dos Estados Unidos, quanto os territórios da América Latina, possuíam enclaves escravistas importantes e lucrativos, dependentes dessa mão de obra. Por isso, a abolição gradual nesses lugares foi alvo de muitos embates e idas e vindas nas legislações, prejudicando as populações a serem libertadas e causando fissuras na classe dirigente (PASSARINI SOUSA, 2021b, p.60).

O estado da Pensilvânia foi o primeiro a aprovar uma legislação de emancipação gradual em 1780, estipulando um prazo para que os proprietários registrassem as crianças nascidas de mulheres escravizadas. Os rebentos que não fossem registrados deveriam ser libertados. Após o fim do prazo, os proprietários que não haviam realizado o registro abarrotaram a assembleia do estado com petições para extensão do prazo. A assembleia aceitou estender o prazo até 1782, o que significava reescravizar pessoas que já deveriam ter sido emancipadas pela lei. Em 1788, foi expedida uma emenda com o objetivo de coibir violações da lei. Ela proibia proprietários de transportarem mulheres escravizadas grávidas para outros estados (principalmente os estados do Sul escravista) com a intenção de que as crianças nascessem escravas, estipulava multas para o sequestro de escravos e proibia a separação de famílias negras por distâncias maiores do que dez 
milhas. A análise destes dispositivos revela uma infinidade de meios utilizados pelos senhores para descumprirem a lei e impedirem ao máximo a emancipação dos escravizados (PASSARINI SOUSA, 2021b, p.67).

Em Nova York, lugar onde o discurso em favor da escravidão era muito forte, a emancipação gradual só foi aprovada em 1799, apenas quando, depois de muitas disputas, o direito de abandonar as crianças nascidas de mulheres escravizadas foi finalmente garantido aos senhores, os quais receberiam uma taxa de reembolso. As crianças, nesta situação, poderiam ser mandadas para outros senhores após decisão de abandono, ou para os mesmos 'proprietários' que haviam abandonando-as, nas mesmas condições, fato que levou autores a considerarem essa cláusula como um esquema disfarçado de compensação aos proprietários (PASSARINI SOUSA, 2021b, p.179). A lei de Rhode Island, aprovada em 1790, foi a única dentre as experiências norte-americanas a estipular que as crianças deveriam "permanecer com suas mães um tempo conveniente após seu nascimento", além de destinar o encargo financeiro ao poder público, que deveria supervisionar os serviços e contratos de trabalho. Contudo, isso foi revogado posteriormente por uma emenda que, seguindo os demais modelos, transferiu os encargos e as responsabilidades inteiramente aos particulares (PASSARINI SOUSA, 2021a, p.177-178).

$\mathrm{Na}$ América Latina, as leis de ventre livre estão inseridas no contexto de formação das repúblicas e guerras de independência contra a coroa espanhola. As duas regiões do Império Espanhol na América, continental e ilhas do Caribe, tiveram processos diferenciados, sobretudo em relação à escravidão. Embora tenha sido o mais vasto e mais duradouro no continente americano, na metade do século XIX o império hispânico na América conservava apenas suas possessões no Caribe. As legislações sobre o ventre escravo foram aprovadas no início dos conflitos por independência, funcionando como um estímulo para a participação de contingentes negros, livres e escravizados; ou no final, como uma forma de compensar o serviço militar prestado pela população negra.

O Chile foi o primeiro dos países latino-americanos a aprovar uma lei de ventre livre, em 1811. A lei, para evitar fraudes, estipulava que mulheres vendidas para fora do país teriam seus ventres livres, bem como o fruto deles: "no se prive de ese beneficio a las madres que sean 
vendidas para fuera del país, se declaran igualmente libres sus vientres, y que deben serlo por consiguiente sus productos en cualquiera parte" (CHILE, 1846, p.29). Examinando registros judiciais no Chile entre 1810 e 1823, Carolina González aponta a recepção de 'novas ideias' que circulavam nos espaços públicos pelos tribunais de justiça, segundo a autora, a documentação judicial revisada revela que o decreto de 1811 mudou os argumentos até então utilizados nos tribunais. Os litígios perpetrados por mães, escravizadas ou libertas, mostram uma oposição entre a figura de uma mãe amorosa e um senhor tirânico e cruel (GONZÁLEZ UNDURRAGA, 2017, p.122). González mostra também como a questão do ventre esteve presente em disputas muito antes de 1811, quando mulheres escravizadas buscaram, ainda no século XVII, comprovar a ascendência indígena de suas mães, refutando a lógica de escravização determinada pelo partus sequitur ventrem (GONZÁLEZ UNDURRAGA, 2021). ${ }^{38}$

Em 1813, o congresso das Províncias Unidas do Rio da Prata decretou a liberdade do ventre escravo com a publicação posterior de um regulamento para a educação dos libertos. Às crianças foi negado o status de ingênuas. Elas seriam consideradas libertas, distinção importante, segundo Magdalena Candioti, porque significava ter uma dívida com os senhores das mães, a quem deveriam servir até completarem vinte anos. Segundo o regulamento, os libertos deveriam ser amamentados por pelo menos doze meses, sendo que caso as mães fossem vendidas, aqueles menores de dois anos deveriam acompanhá-las (CANDIOTI, 2016, p.5). Além disso, foi estabelecido o regime de patronato sobre as crianças, no qual elas ficariam sob jurisdição dos patronos, configurando um espaço ambíguo tanto para o status civil das crianças quanto para o exercício materno das escravizadas (SECRETO, 2021, p.271), ambos tutelados. Ao contrário do Chile, a lei de 1813 não protegeu mulheres grávidas vendidas para outras localidades e embora não fossem mais legalmente escravos, os expedientes judiciais mostram como os filhos seguiram atrelados ao status de suas mães, de quem dependiam muitas vezes para saírem de uma situação de semi-escravidão (GUZMÁN, 2018, p.458).

\footnotetext{
38 A escravidão indígena no Novo Mundo já havia sido proibida em 1542, porém, entre disputas voltou a ser legalizada em 1608, decisão revogada em 1674, sendo definitivamente abolida em 1679. Ver: GONZÁLEZ, 2021, p.9.
} 
Situado em um complexo panorama de disputas políticas e territoriais que envolviam Espanha, Portugal, Buenos Aires e Brasil na região do Prata, o Uruguai foi palco de idas e vindas na legislação. Em meio à disputa por independência no vice-reino do Prata, Montevidéu, que antes respondia a Buenos Aires, permaneceu leal à Coroa Espanhola e em conflito com os portenhos. Quando a Assembleia das Províncias Unidas aprovou a Lei do Ventre Livre, em 1813, ela acabou tendo efeito em algumas partes do Uruguai, mas as disputas na região dificultaram sua aplicação, que ficou à cargo dos tribunais. Além disso, o período de dominação luso-brasileiro acabou determinando a inoperância das medidas de emancipação gradual, momento em que houve um aumento da população escrava devido ao estabelecimento de estancieiros brasileiros na região do Prata. Apenas em 1825 foi sancionada uma lei de proibição ao tráfico, que também declarou a liberdade dos ventres, com previsão de um regulamento posterior. (PASSARINI SOUSA, 2021b, p.85).

Um projeto de lei no Uruguai, datado de maio de 1838 (URUGUAI, 1906, p.443), procurava regular a situação das crianças nascidas livres, constituindo uma fonte interessante a ser analisada. Reforçando as leis de 1825 e $1830^{39}$, o projeto define a idade a que estariam sujeitos ao patronato, mulheres até os 18 e homens até os 20, permitindo a transferência do direito ao patronato mediante pagamento de taxa. O projeto estabelecia que se escravizados tivessem filhos sujeitos ao patronato, mas não estivessem sob o domínio de seus senhores naquele momento, os pais poderiam levar seus filhos consigo, caso a criança ainda não tivesse completado três anos, pagando a taxa mencionada anteriormente. Em sequência, o artigo $4^{\circ}$ afirma que as mães eram aquelas "em melhores condições - do que qualquer estranho - para o resgate do direito ao patronato em caso de transferência” (URUGUAI, 1906, p.443) e mais importante: o patrono não poderia ficar com a criança, caso a mãe quisesse (e pudesse) resgatá-lo. Por fim, o direito de a mãe 'reaver' o filho é certificado pelo artigo subsequente, sem possibilidade de contestação por parte do patrono/senhor (PASSARINI SOUSA, 2021b, p.86).

\footnotetext{
39 A Constituição de 1830 reafirmou a lei de 1825 e suas disposições, segundo o artigo $131^{\circ}$ : "En el territorio del Estado, nadie nacerá ya esclavo; queda prohibido para siempre su tráfico e introducción en la República". 
É possível que este projeto não tenha sido aprovado em vista das possibilidades concretas que abria para a família, sobretudo para as mães, de tirar seus filhos do domínio dos senhores. A decisão das mães pelo projeto seria prioritária, superando os direitos de propriedade ou patronato. O projeto pode nos fornecer pistas sobre a viabilidade de penetração dos discursos emergentes sobre maternidade no Uruguai e como o contexto de abolição da escravidão procurava incorporar as mulheres negras - escravizadas e libertas - a este discurso. Diz-nos algo também sobre a atuação de mulheres escravizadas, que a todo momento estiveram - e mais ainda após a aprovação de leis de ventre livre - tensionando o sistema escravista, demandando suas liberdades e de seus filhos.

As legislações de libertação do ventre estiveram indissociavelmente ligadas a ideologias circulantes sobre a aprendizagem e tutela da população negra, demonstrando que apesar das especificidades de cada um desses lugares, existiu uma articulação em nível atlântico que pretendia atender à emergência de novas lógicas de regime contratual de trabalho. As leis de ventre livre estabelecem períodos de trabalho para crianças e adultos, tutelados por antigos senhores. O Peru, por exemplo, decretou em 1839 a extensão do período de servidão dos que haviam nascido após 1821 - data da libertação do ventre - e a partir daquele momento essas pessoas só atingiriam a liberdade aos 50 anos (PASSARINI SOUSA, 2021b, p.82). A ideia de que as populações recém saídas da escravidão precisariam 'aprender' a viver em liberdade buscava camuflar tentativas evidentes de controle e cerceamento dos libertos, protelando cada vez mais o acesso à liberdade. Apesar das idas e vindas, dos esquemas de trabalho forçado e tentativas de prolongar a servidão ao máximo, é fundamental ressaltar que essas leis abriram o campo para disputas judiciais por parte dos cativos, sobretudo na América Latina. Ainda assim, novos protocolos de trabalho livre passaram a ser ensaiados nas sociedades escravistas, tendo sido, conforme observado por estudiosos no período pós-abolição, frágeis e fluidos (ARIZA, 2017).

\section{Considerações finais}


A consolidação da escravidão nas Américas foi garantida pelo tráfico e pela hereditariedade do cativeiro, determinada pela via materna. Combinados, o princípio do partus sequitur ventrem e a exclusão da mulher negra escravizada do status de vítima em leis que puniam o estupro foram elementos cruciais e garantidores da reprodução, natural e estrutural, da escravidão. Os diferentes 'ritmos' de implementação do partus em contextos diversos e as discussões suscitadas mostram como a hereditariedade do cativeiro nada teve de natural, além disso, evidencia como estas questões impactaram profundamente o cotidiano escravista e as experiências vividas por mulheres escravizadas, tanto na abolição quanto no processo de abolição.

Enquanto a emancipação gradual estava sendo discutida, o movimento abolicionista se consolidava na Inglaterra e depois nos Estados Unidos, entre 1780-1850. O discurso abolicionista passou a se identificar como uma causa essencialmente humana e sentimental, tradicionalmente identificada com uma suposta 'natureza feminina', o que deu margem à participação de mulheres no movimento. Neste contexto, conforme visto, há uma mudança de concepção e representação sobre as mulheres escravizadas, na qual elas passam a ser agentes fundamentais para a abolição gradual, fosse por meio de políticas de incentivo à natalidade, como nas colônias britânicas do Caribe, ou pela libertação do ventre escravo, promovida por toda a América. Essas políticas interferiram diretamente sobre o cotidiano e corpo de mulheres escravizadas, uma vez que incidiam sobre a reprodução e maternidade. Embora a preocupação fosse 'moldar' os filhos dessas mulheres para (não tão) novos regimes de trabalho, as mulheres escravizadas também se apropriaram dos discursos sobre a maternidade, bem como das legislações que libertavam seus ventres, e disputaram suas liberdades e de seus filhos nos tribunais (COWLING, 2018).

No último terço do século XIX, procurando evitar desfechos violentos como os do Haiti e Estados Unidos, Brasil e Cuba, últimos bastiões da escravidão nas Américas, também iniciaram seus processos de abolição gradual mediante a libertação do ventre escravizado. Esses processos evidenciam como desde a implementação da escravidão nas Américas, garantida pelo partus sequitur ventrem e a matrilinearidade da escravidão, o ventre escravo foi determinante para uma 
'tradição' atlântica da escravidão. Reprodução e maternidade foram veículos pelos quais os significados raciais se concretizaram no mundo escravista e a escravidão foi um alicerce para que as relações de poder nessas sociedades se consolidassem também com base em categorias de gênero. Coube às mulheres negras gestar a escravidão e a abolição.

\section{Referências Bibliográficas}

ALFONSO X. Las Siete Partidas. Biblioteca Virtual Universal. Disponível em: $<\underline{\text { https://www.biblioteca.org.ar/libros/130949.pdf }>}$

ALTINK, Henrice. Representations of Slave Women in Discourses of Slavery and Abolition 1780-1838, The University of Hull. Cardiff, Wales, 2002.

ANDREWS, George R. América Afro-Latina, 1800-2000. São Carlos: EdUFSCar, 2014.

ARIZA, Marília Bueno de Araújo. Mães infames, rebentos venturosos: Mulheres e crianças, trabalho e emancipação em São Paulo (século XIX). [Tese de doutorado], Faculdade de Filosofia, Letras e Ciências Humanas, Universidade de São Paulo, 2017.

BROWN, Kathleen M. Good Wives, Nasty Wenches \& Anxious Patriarchs. Philadelphia-PA: University of Pennsylvania Press, 1996.

BUSH, Bárbara. B. "Hard Labor: Women, Childbirth, and Resistance in British Caribbean Slave Societies". In: GASPAR, David e HINE, Darlene (eds.). More Than Chattel: Black Women and Slavery in the Americas. Bloomington and Indianapolis: Indiana University Press, 1996, p.193-217.

CANDIOTI, Magdalena. “Abolición gradual y libertades vigiladas en el Río de la Plata. La política de control de libertos de 1813”. Corpus [En línea], Mendonza, v. 6, n. 1, 2016.

CHAVES MALDONADO, María Eugenia. Honor y Libertad. Discursos y recursos en la estrategia de libertad de una mujer eslava. Gotemburgo: Universidad de Gotemburgo, 2001.

- "Paternalismo, iluminismo y libertad. La vigencia de la Instrucción esclavista de 1789 y su impacto en la sociedad colonial", in: Historia y Sociedad, Medellín, n. 21, dic. 2011. p. 64 Disponível

em http://www.scielo.org.co/scielo.php?script=sci arttext\&pid=S012184172011000200004\&lng=es \&nrm=iso. Acesso em 20 jun. 2021 
"Colección de las leyes i decretos del gobierno desde 1810 hasta 1823: Publicada con la autorización i revisión competente", in: Gaceta ministerial. Santiago: Imprenta chilena, 1846.

COWLING, Camillia. Concebendo a Liberdade: mulheres de cor, gênero e abolição da escravidão nas cidades de Havana e Rio de Janeiro. Campinas: Editora Unicamp, 2018.

DAVIS, Angela. Mulheres, raça e classe. São Paulo: Boitempo, 2016.

DAVIS, David Brion. O Problema da escravidão na cultura ocidental. Rio de Janeiro: Civilização brasileira, 2001.

DRESCHER, Seymour, Abolição: uma história da escravidão e do antiescravismo. São Paulo: Editora Unesp, 2011.

hooks, bell. E eu não sou uma mulher? Mulheres negras e feminismo. Rio de Janeiro: Rosa dos Tempos, 2020.

GONZÁLEZ UNDURRAGA, Carolina. La esclavitud en los registros judiciales y en las leyes de libertad (Chile, 1810-1823). In: MÁRQUEZ, Jaime Valenzuela (ed). América en diásporas. Esclavitudes y migraciones forzadas en Chile y otras regiones americanas (siglos xvi-xix). Santiago: RIL editores - Instituto de Historia, Pontificia Universidad Católica de Chile, 2017, p.113-129

Mujeres esclavizadas y el uso del partus sequitur ventrem ante la justicia: inscribir la ascendencia materna e intervenir el archivo género-racializado en Chile colonial. Estudios del ISHIR, Universidad Nacional de Rosario, v.11, n³0, 2021, p.1-37.

GUZMÁN, Florencia. “¡Madres negras tenían que ser! Maternidad, emancipación y trabajo en tiempos de cambios y transformaciones (Buenos Aires, 1800-1830)", Tempo, vol. 24, n 3 , 20108, p. 450-473.

KLEIN, H. S.; ENGERMAN, S. L. Fertility differentials between slaves in the United States and the British West Indies: a note on lactation practices and their possible implications.The William and Mary quarterly, v. 35, n. 2, 1978, p. 357-374.

LARA, Silvia Hunold. "Legislação sobre Escravos Africanos na América Portuguesa", in: José Andrés-Gallego (coord). Nuevas Aportaciones a la Historia Jurídica de Iberoamérica. Madrid: Fundación Histórica Tavera/Digibis/Fundación Hernando de Larramendi, 2000.

LUCENA SALMORAL, Manuel. "Leyes para esclavos: El ordenamiento jurídico sobre la condición, tratamiento, defensa y represión de los esclavos en las colonias de la América 
española" [Recurso electrónico], in: Tres grandes cuestiones de la historia de Iberoamérica: ensayos y monografías. Madrid: Fundación Ignacio Larramendi, 2011.

MACHADO, Maria Helena Pereira Toledo. "Escravizadas, libertandas e libertas: qualliberdade?”. In: LIMA, Ivana Stolze, GRINBERG, Keila, REIS, Daniel Aarão (orgs.). Instituições Nefandas. O fim da escravidão e da servidão no Brasil, nos Estados Unidos e na Rússia. Rio de Janeiro: Fundação Casa de Rui Barbosa, 2018a, p.327-338.

MACHADO, Maria Helena P.T., "Mulher, Corpo e Maternidade", in: SCHWARZ, Lilia Moritz, e GOMES, Flávio dos Santos (org.). Dicionário da Escravidão e Liberdade. São Paulo: Cia das Letras, 2018b, p.334-340.

MARTINS, Roberto Borges. "Códigos negros e políticas pronatalist em Cuba Colonial", in: XII Congresso Brasileiro de História Econômica \& $13^{a}$ Conferência Internacional de História de Empresas. Niterói, 2017.

MORGAN, Jennifer L., Laboring Women: Reproduction and Gender in New World Slavery. Pennsylvania: University of Pennsylvania Press, 2004.

. "Partus sequitur ventrem: Law, Race, and Reproduction in Colonial Slavery". Small Axe: A

Caribbean Journal of Criticism, March 2018, 22 (1 (55)): 1-17. [https://read.dukeupress.edu/small-axe/article-pdf/22/1]

MORGAN, K. Slave women and reproduction in Jamaica, c.1776-1834. History, v. 91, n. 302, 2006, p.231-253.

MORRIS, Thomas. Southern Slavery and the Law (1616-1860). Chapel Hill: University of North Carolina Press, 1996.

OLIVEIRA, Cleiton. A prole de Caim e os descendentes de Cam: legitimação daescravidão em Portugal e a influência das Bulas Dum diversas (1452) e Romanus Pontífex (1455). [Dissertação de Mestrado]. Instituto de Ciências Humanas e Letras, Universidade Federal de Alfenas, 2018.

PASSARINI SOUSA, Caroline. As primeiras experiências de ventre livre no mundo atlântico: norte dos Estados Unidos e América Latina (17801842). In: MACHADO, Maria Helena; BRITO, Luciana; VIANA, Iamara; GOMES, Flávio. (Org.). Ventres Livres? Gênero, maternidade e legislação. São Paulo: Editora Unesp, 2021a, p. 167-188.

. TARDIVO, Giovana Puppin; HAACK, Marina Camilo. "Localizando a mulher escravizada nos Mundos do Trabalho", in: Revista Cantareira, n. 34, 2021, p.54-75.

. Partus sequitur ventrem: reprodução e maternidade no estabelecimento da escravidão e 
abolição nas Américas até a primeira metade do século XIX. [Dissertação de mestrado]. Faculdade de Filosofia, Letras e Ciências Humanas, Universidade de São Paulo, 2021b.

. Raça, gênero e maternidade: as mulheres escravizadas na proposta de emancipação gradual de José Bonifácio. Em Tempo de Histórias, v. 1, n. 36, jul. 2020, p.177-195.

PAUGH. Katherine. The Politics of Reproduction: Race, Medicine and Fertility in the Age of Abolition. Oxford: Oxford University Press, 2017.

SCOTT, Joan W. "Gênero: uma categoria útil de análise histórica", in: Educação e Realidade, v. 16, n. 2, Porto Alegre, jul./dez. 1990. p. 71-99.

SCOTT, Rebecca J. e HÉBRARD, Jean M. Provas de Liberdade: Uma odisseia atlântica na era da emancipação. Campinas: Editora Unicamp, 2014.

SECRETO. Maria Verónica. Maternidades negras antes e depois do regulamento para a educação e exercício dos libertos de 1813 (Buenos Aires entre o final do século XVIII e o Instituto do Liberto). In: MACHADO, Maria Helena; BRITO, Luciana; VIANA, Iamara; GOMES, Flávio. (Org.). Ventres Livres? Gênero, maternidade e legislação. São Paulo: Editora Unesp, 2021, p.255-276.

SILVA JÚNIOR, Waldomiro Lourenço da. História, direito e escravidão: a legislação escravista no Antigo Regime ibero-americano. São Paulo: Annablume; Fapesp, 2013.

TELLES, Lorena Féres da Silva. "Teresa Benguela e Felipa Crioula estavam grávidas": maternidade e escravidão no Rio de Janeiro (século XIX). [Tese de doutorado], Faculdade de Filosofia, Letras e Ciências Humanas, Universidade de São Paulo, 2018.

TURNER, Sasha. Contested Bodies. Pregnancy, Childrearing, and Slavery in Jamaica. Philadelphia: PENN. University of Pennsylvania Press. 2017.

URUGUAI. Actas de la H. Camara de Representantes, Tomo III, Años 1837-1841. Montevideo: Imprenta El Siglo Ilustrado, 1906, p. 443-444.

WELTER, Barbara. "The Cult of True Womanhood 1820 -1860.", in: American Quarterly: Publication of American Studies Association. Baltimore, v. 18, n. 2, 1966. p. 151-174. 